\title{
On the Prediction of Personal Stature from Cranial Dimensions
}

\author{
Predicción de la Estatura Personal desde Dimensiones Craneales
}

Isurani Ilayperuma

ILAYPERUMA, I. On the prediction of personal stature from cranial dimensions. Int. J. Morphol., 28(4):1135-1140, 2010.

SUMMARY: Dimensional relationship between body segments and stature has been the focus of scientists for many years. All such studies were based on the fact that body segments exhibit consistent ratios relative to the stature and these ratios are linked to age, gender and race. Racial characters are best defined in the skull. Therefore, prediction of stature from cranial remains is vital in establishing the identity of an unknown individual. Despite its significance, little is known concerning the cranial dimensions in Sri Lankans. Hence, this study was designed to investigate the relationship and to propose a gender and age specific linear regression model between the cranial dimensions and height of an individual. A total of 400 subjects with an age span of 20-23 years were included in the study. The cranial length, breadth and auricular head height of the subjects were recorded using a digital sliding caliper and Todd's head spanner capable of measuring to the nearest $0.01 \mathrm{~mm}$. The height of the individual was measured standing erect, in anatomical position using a standing height measuring instrument. The findings indicated significant gender differences in all the mean cranial dimensions. Positive correlations between all cranial dimensions and stature were observed. Linear regression models for the prediction of stature from the above dimensions were formulated for both sexes. Cranial dimensions provide an accurate and reliable means in estimating the height of an individual. The regression formulae derived in this study will be of potential use in clinical, medico-legal, anthropological and archeological studies.

KEY WORDS: Cranial dimensions; Stature; Regression analysis; Sri Lanka.

\section{INTRODUCTION}

It is known that body segments exhibit consistent ratios among themselves and relative to the total body height. The ratios between body segments are age, sex and race dependent (Jantz \& Jantz, 1999; Williams et al., 2000). Reconstruction of stature from various bones of the human skeleton has been achieved by many scientists with varying degree of accuracy (Krishan, 2007). Establishment of alternative methodologies for personal height estimation is important for a number of reasons. Firstly, in instances where height estimates needed to be made from fragments of bones in archeological procedures or in forensic examinations after mass disasters or genocide (Krishan, 2007). Secondly, estimates of pharmacokinetic parameters and evaluation of nutritional status rely on accurate measurement of not only body weight but also height. However, a number of common disease or deformities of the vertebral column make it difficult to accurately measure standing height in many patients (Auyeung et al., 2009).

Evidence shows a clear racial variation in the cranial dimensions among different populations such as Koreans, Caucasians, Indians, Turkman and native Fars groups, Turkey, Zulu populations and Mapuche individuals in Chile (Hwang et al., 1995; Dekaban, 1977; Manjunath, 2002a; Thomas et al., 1980; Golalipour et al., 2005; Acer et al., 2007; Ricklan \& Tobias, 1986; del Sol, 2005). Therefore, knowledge on the cranial morphometry is important in the study and comparison of the crania of populations from different racial, geographic and dietary backgrounds. Such information is also useful in studies of primate phylogeny. In clinical practice, population and age specific data on cranial dimensions gives an indication of growth and development of an individual and also any abnormalities of cranial size and shape (Harper et al., 1984).

The problem of correlating the various metric traits of the skeletal remains with the stature of an individual has confronted scientists for a long time. Although a wide variety of long bones have been employed for stature estimation only few studies have utilized the cranial dimensions in this regard (Jadav \& Shah, 2004; Krishan, 
2007; Sarangi et al., 1981). Cranial dimensions have been shown to be a reliable and precise means in predicting the stature in Italian (Introna et al., 1993), Japanese (Chiba \& Terazawa, 1998), Indian (Patil \& Modi, 2005; Krishan, 2007) and South African populations (Ryan \& Bidmos, 2007). Although many formulae for stature estimation have been proposed, there is concern regarding the accuracy of the use of population specific formulae on other human populations (Williams et al.; Duyar \& Pelin, 2003). It is obvious that there are no universally applicable formulae as the relationship between head dimensions and cranial capacity is influenced by the race, sex and age of an individual. Thus, the need for race, age and sex specific stature estimation formulae is proved beyond doubt (Krishan, 2007).

Despite its significance and potential practical utility, little is known concerning the relationship between cranial dimensions and stature among Sri Lankans, inhabitants of the South Asian country. Hence, this study was designed to elucidate the norms for cranial dimensions and to propose population and gender specific regression models for stature estimation using the linear dimensions of the crania.

\section{MATERIAL AND METHOD}

This study was conducted in 400 medical students (220 male and 180 female) of the Faculty of Medicine, University of Ruhuna, Galle, Sri Lanka. The subjects were apparently healthy and without any craniofacial deformity. They were from different parts of the island belonging to different socio-economic status. The age of the subjects ranged from 20-23 years.

The height of the individual was measured between vertex and the floor, when the person is standing erect, in anatomical position and the head in the Frankfort plane, using a standing height measuring instrument. Height was measured to the nearest $0.1 \mathrm{~cm}$.

The following external linear dimensions of the skulls were recorded (Williams et al.).

1. Maximum cranial length (glabella - inion length). It is defined as the straight distance between the most prominent point on the frontal bone above the root of the nose (glabella) and the most prominent portion of the occipital bone. This was measured by placing the anterior caliper tip on glabella while allowing the posterior caliper tip to slide inferiorly along the median plain of the occipital bone until the maximum length was reached.
2. Maximum cranial breadth (maximum biparietal diameter). It is defined as the maximum distance between the most lateral points of the parietal bones. This was measured by allowing both tips of the spreading caliper to slide down along the lateral aspects of the parietal bones until the maximum width was recorded.

Maximum antero-posterior cranial length and maximum cranial breadth were measured using a digital spreading caliper (Mitutoyo, Japan) capable of measuring to the nearest $0.01 \mathrm{~mm}$.

3. Auricular head height. It is defined as the distance between the external acoustic meatus and the highest point of the vertex (bregma). The measurement was recorded on both sides using the Todd's head spanner.

The above measurements were recorded at a fixed time between $14.00-16.30$ hours to eliminate discrepancies due to diurnal variation. All the measurements were repeated thrice and the mean was taken for further analysis. Furthermore, the measurements were recorded by the same person to minimize the errors in methodology.

The degree of sexual divergences in cranial dimensions was calculated as follows (Hwang et al.): The index of sexual dimorphism $=$ male mean - female mean $/$ male mean $\mathrm{x} 100 \%$.

Results were expressed as mean \pm SD and analyzed using the Statistical Package for Social Sciences (SPSS), 15 th version. A comparison of the mean values between the genders was performed using the t-test. $\mathrm{P}$ value $<0.05$ was considered statistically significant.

\section{RESULTS}

The mean ages of the study subjects (male: $21.03 \pm$ 0.88 ; female $21.27 \pm 0.89$ ) were not significantly different between genders (Table I). The mean height of the study population was found to be significantly different $(\mathrm{P}<0.001)$ between genders. Gender differences with respect to the mean cranial length, cranial breadth and auricular head height were found to be significantly larger in males compared to females $(\mathrm{P}<0.001)$ (Table I).

The index of sexual dimorphism in cranial length, breadth and auricular head height were $4.5 \%, 2.9 \%$ and $4.1 \%$ respectively.

Linear regression analyses were performed for 
estimation of stature using the cranial length, cranial breadth and auricular head height as an independent variables. Pearsons' correlation coefficient was used to examine the relationship between various cranial dimensions and personal height according to the gender. Correlation coefficient between the stature and measured cranial dimensions were found to be statistically significant and positive in both males and females (Table II).

Scatter plots and linear regression lines demonstrating the relationship between stature and cranial dimensions are illustrated in Figures 1- 3. Linear regression formulae for the prediction of stature using cranial dimensions were derived as follows:
Regression equation for prediction of stature from cranial length: For male: $101.83+3.69$ (Cranial length); For female: $226.60+3.86$ (Cranial length);

For both male and female (combined): $103.72+3.38$ (Cranial length).

Regression equation for prediction of stature from cranial breadth: For male: $111.61+3.84$ (Cranial breadth); For female: $111.76+$ 3.33 (Cranial breadth);

For both male and female (combined): $764.98+6.04$ (Cranial breadth).

Regression equation for prediction of stature from auricular head height:

For male: $120.88+3.39$ (Head height); For female: $137.64+1.52$ (Head Height);

For both male and female (combined): $128.17+2.55$ (Head height).

Table I. Cranial dimensions and stature of the study subjects.

\begin{tabular}{lcc}
\hline Characteristic & Male & Female \\
\hline Total Number & 220 & 180 \\
Stature $(\mathrm{cm})$ & $162.95 \pm 90.25 *$ & $152.48 \pm 114.98$ \\
Cranial length $(\mathrm{mm})$ & $180.00 \pm 11.12 *$ & $171.92 \pm 10.11$ \\
Cranial breadth $(\mathrm{mm})$ & $140.15 \pm 10.66^{*}$ & $136.15 \pm 11.02$ \\
Auricular head height $(\mathrm{mm})$ & $141.10 \pm 9 *$ & $135.38 \pm 12.16$ \\
\hline
\end{tabular}

$* \mathrm{P}<0.05$.

Table II. Correlation coefficient between stature and cranial dimensions.

\begin{tabular}{lcc}
\hline Parameter & Male & Female \\
\hline Stature \& cranial length & 0.715 & 0.470 \\
Stature \& cranial breadth & 0.312 & 0.454 \\
Stature \& auricular head height & 0.514 & 1.478 \\
\hline
\end{tabular}

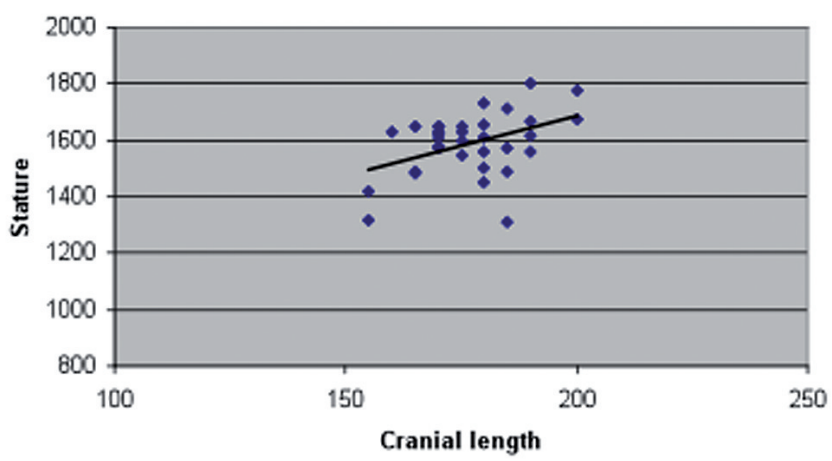

Fig. 1. Scatter plot and regression line demonstrating the relationship between stature and cranial length $(\mathrm{mm})$.

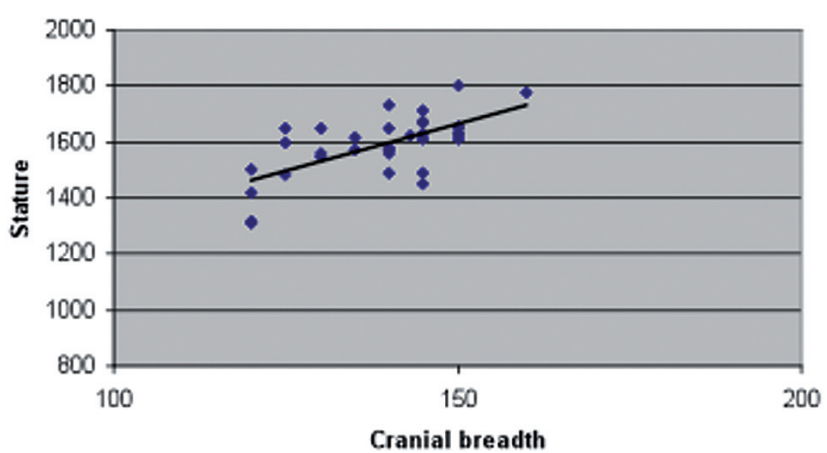

Fig. 2. Scatter plot and regression line demonstrating the relationship between stature and cranial breadth $(\mathrm{mm})$.

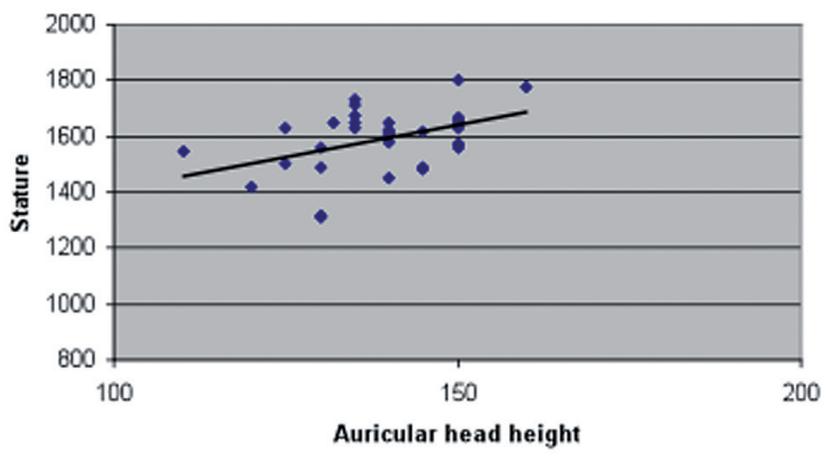

Fig. 3. Scatter plot and regression line demonstrating the relationship between stature and auricular head height ( $\mathrm{mm})$. 


\section{DISCUSSION}

The present study provides valuable new data pertaining to the principal anatomical dimensions of the skulls and its correlation with the stature in adult Sri Lankan population. It is stated that the racial characters are best defined in the skull (Krishan, 2007). As a result cranial dimensions constitute one of the most important characters for determining the racial difference (Hwang et al.; Manjunath, 2002b; Krishan, 2007). Variety of non-metric and metric parameters has been utilized in the assessment of ethnic and gender differences in cranio-facial morphology. The non-metric parameters are subjective as no quantitative techniques are devised. On the other hand, features that can be expressed as actual measurements, like cranial dimensions, provide more objective racial and gender diversity assessment of the crania (Krishan, 2007).

Diverse craniometric approaches have been utilized to estimate the cranial dimensions either on dry skulls or living subjects (Manjunath, 2002b). Over the course of this study external linear dimensions of the skulls were recorded on living subjects. Cephalometry is reliable, relatively easy and quick to apply. Furthermore this approach has the added advantage as it does not require any sophisticated techniques. Taken together, cephalometry continues to be the most versatile technique in the investigations of the craniofacial skeleton (McIntyre \& Mossey, 2003; Vojdani et al., 2009).

The mean cranial dimensions observed in this study were greater than those observed for the Indians, Turkman, Native Fars and Turkey populations (Manjunath, 2002a; Golalipour, et al., 2005; Acer et al.) whereas it was smaller than Koreans and Caucasians (Hwang et al.; Dekaban), a finding that further reinforces the racial diversity in the cranial dimensions. It is speculated that such population diversity in cranial morphometry is attributed to race, age and geographical factors (Ricklan \& Tobias; Golalipour et al., 2003).

Although variety of methodologies have been proposed to predict stature from various bones, regression analysis proved to be the easiest and the most reliable method (Jantz \& Jantz). Correlation coefficients between the total height and all the measured cranial dimensions among Sri Lankans were found to be statistically significant and positive indicating a strong relationship between the two parameters. Previous studies have shown correlation coefficients of 0.20 (Saxena et al., 1981), 0.53 (Jadev \& Sha); \& 0.78 (Krishan, 2008) between cranial length and height, whereas in the present study it was 0.72 which is consistent with the previous studies. Regression models for stature prediction were formulated using all major cranial dimensions and checked for their accuracy by comparing the estimated stature and the actual stature. The results further confirmed that cranial morphometry provides an accurate and reliable means in stature prediction.

It is well known that sexual dimorphism is an important component of the morphological variation in biological populations (Williams et al.). The gender divergence in cranial morphometry observed in our study supports the previous observations (Hwang et al:; Dekaban, Manjunath, 2002a; Golalipour et al., 2005; Acer et al.). This further emphasizes the significance of applying the anatomical variation data to an individual subject in a given population. The need for the alternative formulae for the genders is also proved as the rate of skeletal maturity in males and females vary during the course of growth and development (Williams et al.). The continuing growth of the head and face also exert some effect on the estimation of stature particularly in the adolescent (Krishan, 2008).

In forensic examinations and anthropological studies, prediction of stature from incomplete and decomposing cranial remains is vital in establishing the identity of an unknown individual. Therefore, formulae based on the cranial dimensions provide an alternative stature predictor under such circumstances. The cranium has easily identifiable surface landmarks making the measurements possible even in compromised conditions.

Variety of factors such as age, race, gender and nutritional status affect human development and growth and therefore, different nomograms are required for different populations (Williams et al.). The present study for the first time documents such norms for cranial dimensions and presents gender specific linear regression models for stature prediction in adult Sri Lankan population. These formulae are valid for the age group (20-23 years) of the subjects. It is widely accepted that cranial morphology varies with the age of an individual. (Wolf et al., 2003; Knutson et al., 2001) In addition the height is also shown to progressively decrease with advancing age due to spinal cord shrinkage (Williams et al.). The population, gender and age specific regression models proposed will be of immense practical use in medico-legal, anthropological and archeological studies where the total height of a subject can be calculated if the cranial dimensions are known.

\section{ACKNOWLEDGEMENT}

The author wishes to thank Dr. W. A. A. Wijeyasiri, Department of Community Medicine, Faculty of Medicine, University of Ruhuna, Sri Lanka, for advising with the statistical analysis. 
ILAYPERUMA, I. Predicción de la estatura personal desde dimensiones craneales. Int. J. Morphol., 28(4):1135-1140, 2010.

RESUMEN: Durante muchos años, el foco de los investigadores, ha sido la relación entre segmentos del cuerpo y la estatura. Los estudios se basan en el hecho que segmentos corporales presentan relaciones consistentes con respecto a la estatura y, éstos además, se relacionan con la edad, género y raza. Los caracteres raciales están mejor definidos en el cráneo. Por lo tanto, la predicción de la estatura a través de los restos del cráneo es de vital importancia para determinar la identidad de un individuo. A pesar de su importancia, poco se sabe sobre las dimensiones del cráneo de los individuos de Sri Lanka. Así, fue diseñado esste estudio para investigar estas relaciones y proponer un modelo de regresión lineal específico, para sexo y edad, entre las dimensiones y la altura del cráneo de un individuo. Se estudiaron 400 sujetos con un rango de edad de 20-23. La longitud del cráneo, ancho y altura de la cabeza fueron medidos con un caliper digital deslizante y llave de Todd central, con precisión de 0,01 mm. La altura del individuo fue tomada en posición anatómica. Los resultados indicaron diferencias significativas entre géneros, en todas las dimensiones del cráneo. Fueron observadas correlaciones positivas entre las dimensiones craneales. Se desarrollaron modelos de regresión lineal para la predicción de la estatura de las dimensiones anteriores para ambos sexos. Las dimensiones craneales constituyen un medio preciso y fiable en la estimación de la altura de un individuo. Las fórmulas de regresión obtenidos en este estudio serán de uso potencial en la clínica, médico-legales, y en estudios antropológicos y arqueológicos.

\section{PALABRAS CLAVE: Dimensiones craneales; Estatura; Análisis regresivo; Sri Lanka.}

\section{REFERENCES}

Acer, N., Usanmaz, M.; Tugay, U. \& Erteki'n, T. Estimation of cranial capacity in 17-26 years old university students. Int. J. Morphol., 25:65-70, 2007.

Auyeung, T. W.; Lee, J. S.; Kwok, T.; Leung, J. Leung, P. C. \& Woo, J. Estimation of stature by measuring fibula and ulna bone length in 2443 older adults. J. Nut. Health Aging, 10:931-6, 2009.

Chiba, M. \& Terazawa, K. Estimation of stature from somatometry of skull. Forensic Sci. Int., 97:87-92, 1998.

Dekaban, A. Tables of cranial and orbital measurements, cranial volume and derived indexes in males and female from 7 days to 20 years of age. Ann. Neurol., 2:485-9, 1977.

Del Sol, M. Índice cefálico en un grupo de individuos mapuches de la IX región de Chile. Int. J. Morphol., 23:241-6, 2005.

Duyar, I. \& Pelin, C. Body height estimation based on tibial length in different stature groups. Am. J. Phys. Anthropol., 122:23-7, 2003.

Golalipour, M. J.; Haidari, Jahanshahi, M. \& Frahani, R. M. The shapes of head and face in normal male newborns in southeast of Caspian Sea (Iran-Gorgan). J. Anat. Soc. India, 52:28-31, 2003.

Golalipour, M. J.; Jahanshaei, M. \& Haidari, K. Estimation of cranial capacity in 17-20 years old in South East of
Caspian Sea Border (North of Iran). Int. J. Morphol., 23:301-4, 2005.

Harper, C.; Krill, J.; Raven, D. \& Jones, N. Intracarnial cavity volumes: a new method and its potential applications. Neuropathol. Appl. Neurobiol., 10:25-32, 1984.

Hwang, Y.; Lee, K. H.; Choi, B.; Lee, K. S.; Lee, H. Y.; Sir, W. S. et al. Study on the Korean adult cranical capacity. J. Korean Sci., 10:239-42, 1995.

Introna, F. Jr.; Di Vella, G. \& Petrachi, S. Determination of height in life using multiple regression of skull parameters. Boll. Soc. Ital. Biol. Sper., 69:153-60, 1993.

Jadav, H. R. \& Shah, G. V. Determination of personal height from the length of head in Gujarat Region. J. Anat. Soc. India, 53:20-1, 2004.

Jantz, L. M. \& Jantz, R. L. Secular changes in long bone length and proportion in the United States 1800-1970. Am. J. Phys. Anthropol., 110:57- 67, 1999.

Knutson, B.; Momenan, R.; Rawlings, R. R.; Fong, G. W. \& Hommer, D. Negative association of neuroticism with brain volume ratio in healthy humans. Biol. Psychiatry, 50:685-90, 2001.

Krishan, K. Anthropometry in Forensic Medicine and Forensic Science-'Forensic Anthropometry'. Int. J. Foren. Sci., 2:1, 2007. 
Krishan, K. Estimation of stature from cephalo-facial anthropometry in north Indian population. Forensic. Sci. Int., 181:521-6, 2008.

Manjunath, K. Y. Estimation of cranial volume in dissecting room cadavers. J. Anat. Soc. India., 51:168-72, 2002a.

Manjunath, K. Y. Estimation of cranial volume-an overview of methodologies. J. Anat. Soc. India, 51:85$91,2002 b$.

McIntyre, G. T. \& Mossey, P. A. Size and shape measurement in contemporary cephalometrics. Eur. J. Orthod., 25:231-42, 2003.

Patil, K. R. \& Mody, R. N. Determination of sex by discriminant function analysis and stature by regression analysis: A lateral cephalometric study. Foren. Sci. Int., 147:175-80, 2005.

Ricklan, D. E. \& Tobias, P. V. Unusually low sexual dimorphism of endocranial capacity in a Zulu cranial series. Am. J. Phys. Anthropol., 71:285-93, 1986.

Ryan, I. \& Bidmos, M. A. Skeletal height reconstruction from measurements of the skull in indigenous South Africans. Foren. Sci. Int., 167:16-21, 2007.

Sarangi, A. K.; Dadhi, B. \& Mishra, K. K. Estimating of stature from adult skull bone. J. Ind. Acad. Forensic Med., 182:24-6, 1981.

Saxena, S.K.; Jeyasingh, P.; Gupta, A.K. \& Gupta, C.D. The estimation of stature from head-length. J. Anat. Soc. India, 30:78-9, 1981.

Thomas, I. M.; Janaliram, S.; Rajangam, S. \& Amar, D. S. Cranial capacity of crania from Kamatalka. J. Anat. Soc. India, 29:135-7, 1980.

Vojdani, Z.; Bahmanpour, S.; Momeni, S.; Vasaghi, A.; Yazdizadeh, A.; Karamifar, A.; Najafifar, A.; Setoodehmaram, S. \& Mokhtar, A. Cephalometry in 14-18 years old girls and boys of Shiraz-Iran high school. Int. J. Morphol., 27:101-4, 2009.

Williams, P. L.; Bannister, L. H.; Berry, M. M.; Collins, P.; Dyson, M.; Dussek, J. E. Gray's Anatomy: The anatomical basis of medicine and surgery. $38^{\text {th }} \mathrm{Ed}$. New York, Churchill Livingstone, 2000.

Wolf, H.; Kruggel, F.; Hensel, A.; Wahlund, L. O.; Arendt, T. \& Gertz, H. J. The relationship between head size and intracranial volume in elderly subjects. Brain Res., 23:74-80, 2003.

Correspondence to:

Dr. Isurani llayperuma, Ph.D.

Department of Anatomy,

Faculty of Medicine,

University of Ruhuna,

P.O.Box 70, Galle,

SRI LANKA.

Telephone: 0094-91-2234801

Fax: 0094-91-2222314

Email: iisurani@yahoo.com

Received: 03-07-2010

Accepted: 21-08-2010 